\title{
HISTOLOGICAL APPLICATION OF X-RAY COMPUTED MICROTOMOGRAPHY OF CONODONTS
}

\author{
A. V. Zhuravlev \\ Institute of Geology Komi SC UB RAS, Syktyvkar \\ micropalaeontology@gmail.com
}

The Pa-elements of the Early Carboniferous conodont Siphonodella quadruplicata (Branson et Mehl) were studied at the Skyscan 1272 micro-CT. The obtained results demonstrate three groups of tissues. The first one comprises interlamellar tissue possessing lowest radiodensity, the second group consists of lamellar tissue characterized by intermediate radiodensity, and the paralamellar and albid tissues demonstrate the highest radiodensity. The X-ray computed microtomography (micro-CT) allows reconstructing internal composition of the studyied $\mathrm{Pa}$-elements and improving data about interlamellar tissue distribution. The results demonstrate perspectives of using the micro-CT in the histological study of conodont elements.

Keywords: Conodont, X-ray computed tomography, histology, hard tissues, Early Carboniferous.

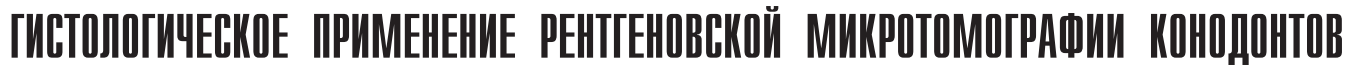

\author{
А. В. Журавлёв \\ Институт геологии Коми НЦ УрО РАН, Сыктывкар
}

По результатам изучения Ра-элементов раннекаменноугольного вида конодонтов Siphonodella quadruplicata (Branson et Mehl) с помощью рентгеновского микротомографа Skyscan 1272 были установлены три группы минерализованных тканей, отличающиеся рентгеновской плотностью. Первая группа включает интерламеллярную ткань и характеризуется самой низкой рентгеновской плотностью. Ко второй группе отнесена ламеллярная ткань, обладающая средней рентгеновской плотностью. Третью группу составляют параламеллярная и альбидная ткани, характеризующиеся самой высокой рентгеновской плотностью. Рентгеновская томография позволяет реконструировать тканевое строение изученных Ра-элементов и уточнить данные о распределении в них интерламеллярной ткани. Полученные результаты демонстрируют перспективность использования рентгеновской микротомографии в гистологических исследованиях конодонтовых элементов.

Ключевые слова: конодонты, рентгеновская микротомография, гистология, твердые ткани, ранний карбон.

\section{Introduction}

The histological features of conodont elements are widely used for taxonomy and deciphering of the conodont affinities (e.g. $[1,10,5])$. Conodont elements are composed of fluorapatite-organic composites [7], organized into a number of hard tissues. The tissues have different content of organic matter and crystalline structure (e.g. [1, 2]). Four types of the hard tissues are known in the conodont element crown: interlamellar, lamellar, paralamellar, and albid. Lamellar and paralamellar tissues are the most common. Interlamellar tissue composes small structures in the conodont element as a rule. Albid tissue composes cores of the denticles of carina only.

The common methods for studying of the conodont element histology are immersion and thin or polished sections. Unfortunately, the former one is not precise, and the latter are destructive for the element studied.

Computed microtomography or Micro-CT is X-ray imaging in 3D, by the same method used in hospital CT (or «CAT») scans, but on a small scale with massively increased resolution. It really represents true $3 \mathrm{D}$ microscopy, where very fine scale internal structure of objects is imaged non-destructively. The Micro-CT is widely used in macropalaeontology $[9,6]$ and micropalaeontology $[4,3,13,5,11]$. Synchrotron microtomography was used for morphological investigations of conodont elements as well [5]. This report is aimed to considering results of application the X-ray microtomography (CT) for histological study of the conodont elements. Difference of physical prop- erties of the conodont hard tissues promises possibility to distinguish them in the $\mathrm{X}$-ray images.

\section{Methods and material}

The present study was based on X-Ray Micro-CT system SkyScan 1272 (Bruker, Belgium) of the «National Mineral Resources University» (Saint-Petersburg, Russia). 3-dimensional reconstructions and sections were made using NRecon, CTVox, DataViewer (SkyScan, Bruker), and Voxler 3 (Golden Software) software. The individual conodont elements extracted from the host rocks were mounted on the polymetilacrilate slab and scanned with an isotropic voxel resolution of $2.0-5.0 \mu \mathrm{m}$ at $50-$ $70 \mathrm{kV}$ source voltage and angular step of $0.1-0.2^{\circ}$. Reconstructions were made with beam hardening correction of $30 \%$ with NRecon software (Bruker, Belgium). Specific features of the micro-CT system used and method of sample preparation had been considered earlier [8].

Robust conodont elements of the Early Carboniferous Siphonodella quadruplicata (Branson et Mehl) obtained from the quadruplicata Zone in the Konstantinov Creek section (Subpolar Urals) were used for the tomographic study. The conodont elements demonstrate good morphological and histological preservation and CAI of 5 .

\section{Results and discussion}

The Pa elements of Siphonodella quadruplicata demonstrate full spectrum of the hard tissues known in conodonts, and are 
well studied histologically with traditional methods [12]. The tissues, differing by organic matter content, crystallite size and orientation, and presence or absence of microcavities, demonstrate some disparity in the radiodensity [13]. However conodont element tomograms show that low absorption contrast makes it impossible to recognize all the tissue types [11, 13]. Only three groups of tissues can be distinguished. The first one comprises interlamellar tissue having lowest radiodensity $\left(0.17 \mathrm{~mm}^{-1}\right.$ at $60 \mathrm{KV}$ and $\mathrm{Al} 0.25 \mathrm{~mm}$ filter $)$, the second group consists of lamellar tissue characterized by intermediate radiodensity $\left(0.25 \mathrm{~mm}^{-1}\right.$ at $60 \mathrm{KV}$ and $\mathrm{Al} 0.25 \mathrm{~mm}$ filter $)$, and the paralamellar and albid tissues demonstrate highest radiodensity $\left(0.27 \mathrm{~mm}^{-1}\right.$ at $60 \mathrm{KV}$ and $\mathrm{Al} 0.25 \mathrm{~mm}$ filter $)[13,11]$. In some cases the albid tissue belongs to the second group.

It is interesting to note that the more spatial resolution of the tomogram is, the less radiodensity contrast between the tissue types is observed (Figure 1). The explanation is that crystallites, composing different tissues, have equal radiodensity close to fluorapatite (about $0.27-0.30 \mathrm{~mm}^{-1}$ ). The integral radiodensity of a tissue depends not only on the radiodensity of the crystallites, but on the porosity, organic matter content, and, in less degree, on the tissue structure (crystallite ordering). High porosity and organic matter content decrease the tissue radiodensity. In opposite, disordered structure leads to increasing of the X-ray attenuation and, hence, the radiodensity. Low radiodensity of the interlamellar tissue reflects a high content of organic matter, intermediate radiodensity of the lamellar tissue is caused by ordered structure, intermediate organic content, and absence of the cavities. High radiodensity of the paralamellar tissue is caused by disordered structure accompanied with low organic content and low porosity. Radiodensity of the albid tissue is determined by extremely ordered structure (porous mesocrystall), lowest organic content, and presence of numerous microcavities [2].

Spatial distribution of the tissue groups in the Pa elements of Siphonodella quadruplicata (Branson et Mehl), studied with the X-ray microtomography (Figure 2), closely corresponds to the distribution observed in the polished sections with SEM (Figure 3). Paralamellar tissue composes sheets located in the platform, cores of the rostral ridges and denticles of the carina (Figure 2).

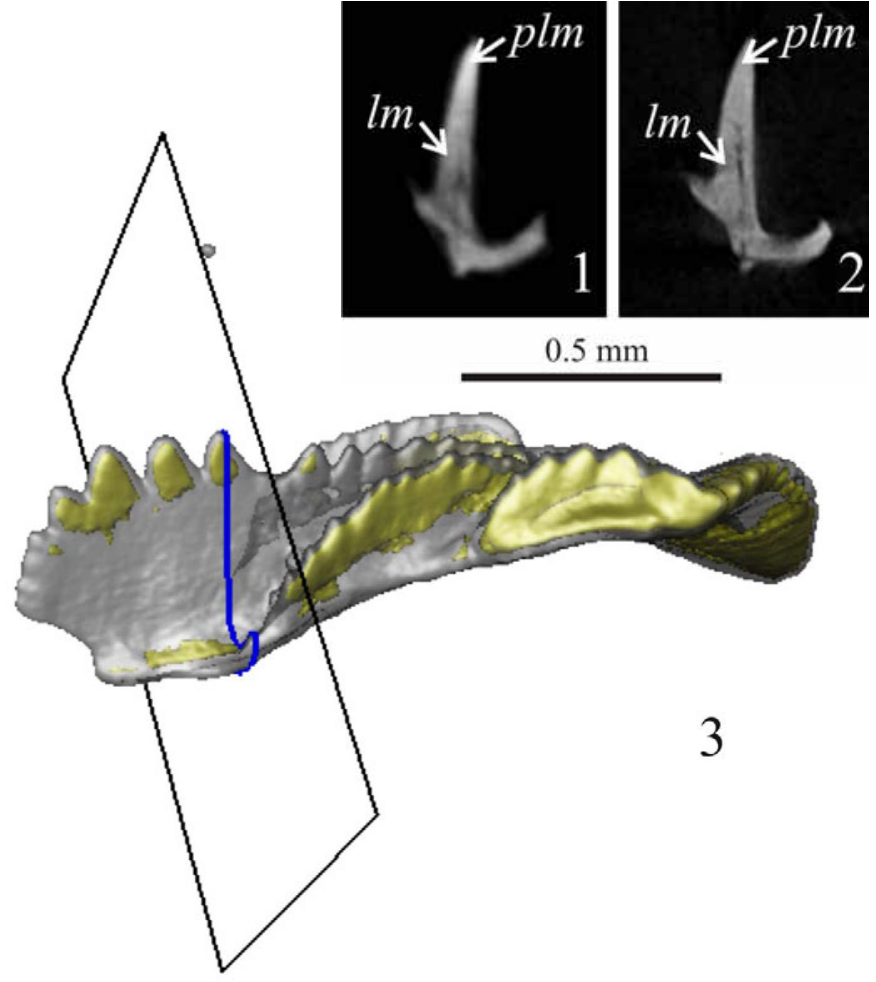

Fig. 1. Slices of the tomograms of the Pa-element of Siphonodella quadruplicata (Branson et Mehl) with different spatial resolution: $1-5 \mu \mathrm{m}$ voxel tomography, paralamellar tissue is light grey, lamellar tissue is grey, and interlamellar tissue is dark grey; $2-2 \mu \mathrm{m}$ voxel tomography, paralamellar and lamellar tissues are grey, interlamellar tissue is dark grey; 3 - Position of the slice showed on the $3 \mathrm{D}$ reconst-

ruction. Legend: $I m$ - lamellar tissue; $p l m$ - paralamellar tissue

Рис. 1. Срезы томограмм Ра-элемента Siphonodella quadruplicata (Branson et Mehl) с различным пространственным разрешением: 1 - воксель $5 \mu \mathrm{m}$, параламеллярная ткань светло-серая, ламеллярная - серая, интерламеллярная - темно-серая; 2 - воксель $2 \mu \mathrm{m}$, параламеллярная и ламеллярная ткани серые, интерламеллярная - темно-серая; 3 - положение сечения на трехмерной реконструкции. Условные обозначения: lm - ламеллярная ткань; plm - параламеллярная ткань
Fig. 2. Siphonodella quadruplicata (Branson et Mehl), Pa-element, sample Tn-19a/99; Sub-Polar Urals, Konstantinov Creek; Lower Carboniferous, Tournaisian, Siphonodella quadruplicata Zone. $5 \mu \mathrm{m}$ voxel tomography: 1, 2- isosurface model, demonstrating distribution of the paralamellar tissue (yellow); 3 - volume model showing distribution of the paralamellar and interlamellar tissues. Legend: plm - paralamellar tissue, ilm - interlamellar tissue, $l m$ - lamellar tissue

Puc. 2. Siphonodella quadruplicata (Branson et Mehl), Ра-элемент, образец Tn-19a/99; Приполярный Урал, руч. Константинов; нижний карбон, турнейский ярус, зона Siphonodella quadruplicata. Томография с размером вокселя $5 \mu \mathrm{m}: 1,2$ - «оболочечная модель», демонстрирующая распределение параламеллярной ткани (желтая); 3 - «твердотельная модель», показывающая распределение параламеллярной и интерламеллярной тканей. Условные обозначения: plm - параламеллярная ткань, $\mathrm{ilm}$ - интерламеллярная ткань, lm - ламел-

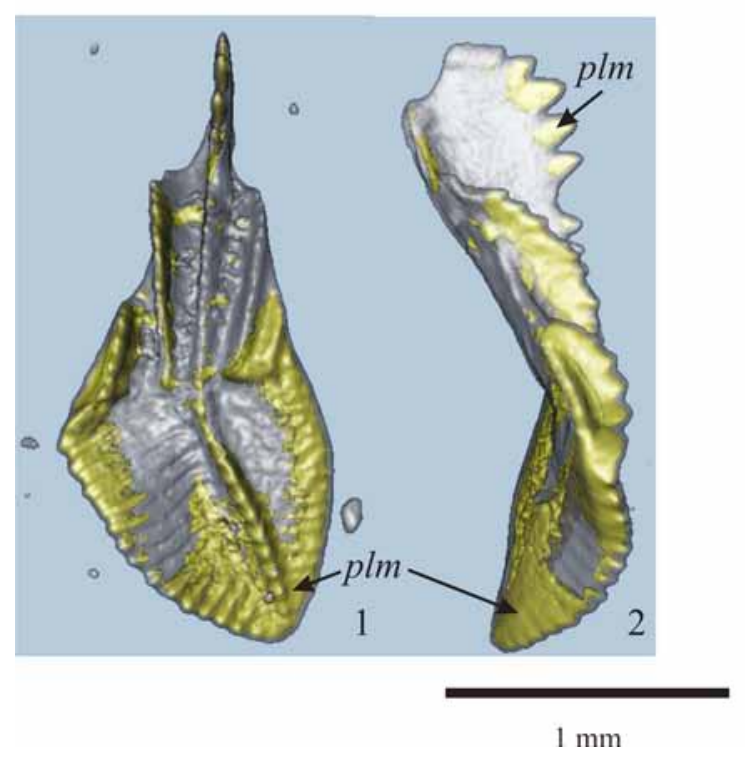

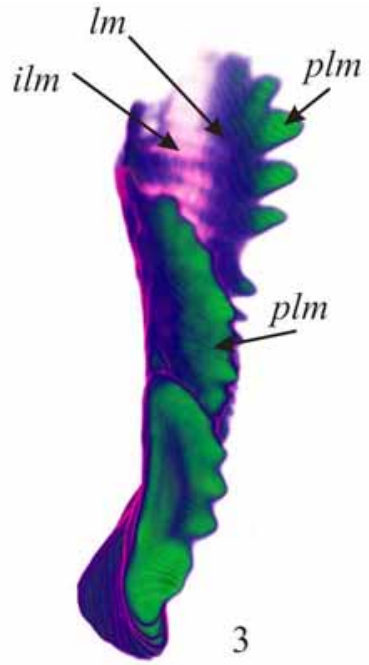

лярная ткань 
According to the data obtained with thin and polished sections, the interlamellar tissue forms thin septa in the free blade, and narrow strips conforming to growth lamella in the anterior part of the rostrum. The tomograms demonstrate that the «septa» of interlamellar tissue in the free blade, detected in the thin sections, is composed by a number of bowed strips $(20-30 \mu \mathrm{m}$ wide, $4-10 \mu \mathrm{m}$ thick) separated by lamellar and paralamellar tissues (Figures 3, 4). Similar, but smaller, strip-like structures of the interlamellar tissue were detected in the lower part of the posterior process, beneath the carina (Figure 5).

\section{Conclusions}

The results obtained allow reconstructing internal composition of the study $\mathrm{Pa}$ elements and improving data about paralamellar and interlamellar tissues distribution. The CT data demonstrate that paralamellar tissue composes cores of the denticles, especially in the posterior carina, upper parts of the rostral ridges, and sheets in the platform (Figure 2); interlamellar tissue composes strip-like structures in the free blade, anterior rostrum, and lower part of the carina (Figure 4, 5).

The results demonstrate perspectives of using the CT in histological study of conodont elements and for producing precise 3D histological models of conodont elements.

Acknowledgments. Author wish to thank A. Zherlygin and A. Shtyrlyaeva (NMSU «Gornyi») for their assistance during micro$C T$ study of conodont elements, and anonymous reviewer for constructive remarks. The investigations were supported by the Uralian Branch of RAS Grant \#15-18-5-37.
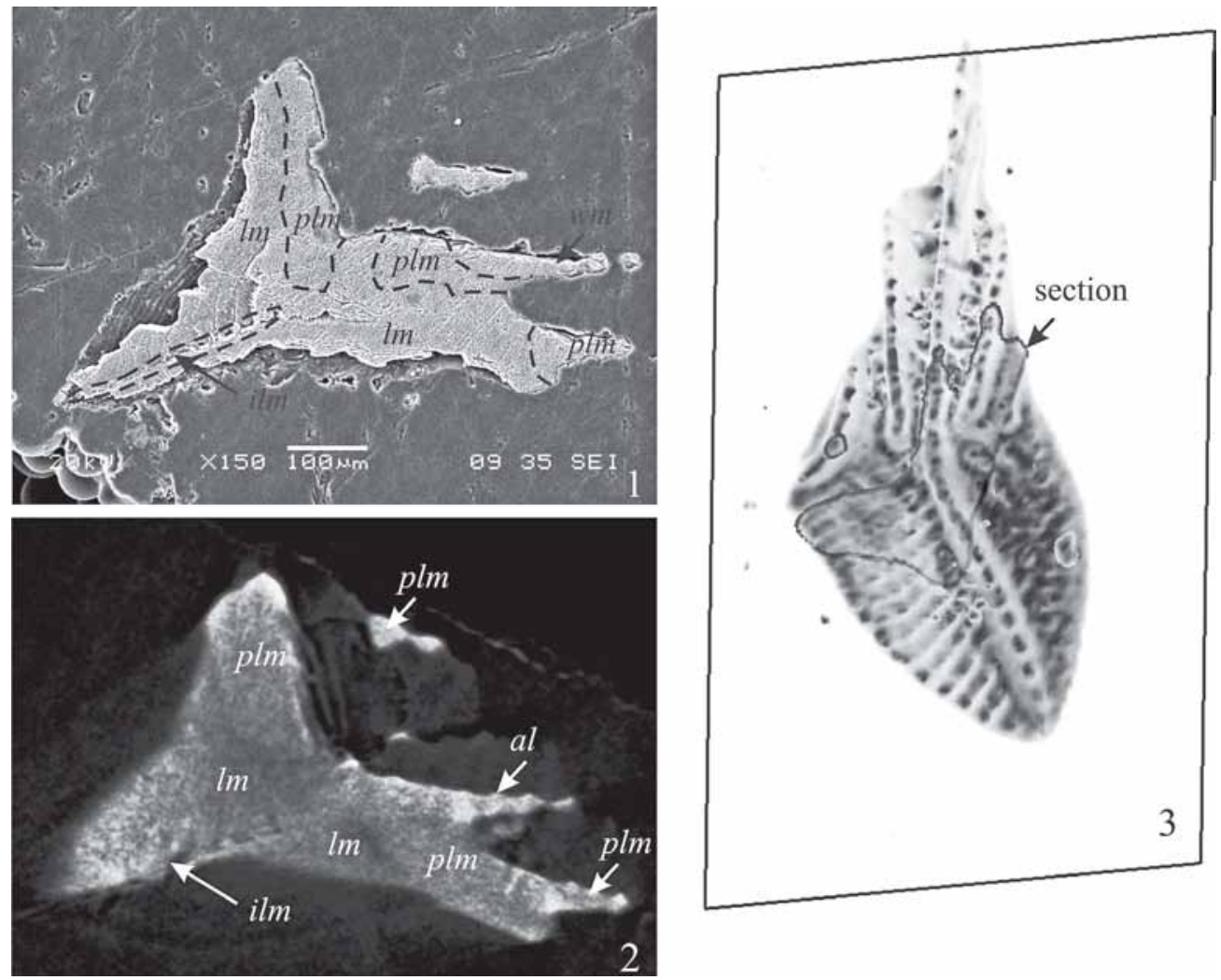

Fig. 3. Distribution of the hard tissues in the Pa-elements of Siphonodella quadruplicata: 1 - SEM-image of the oblique polished section; 2 - tomogram slice corresponding to the section in the Figure 3.1;3 - position of the section. Legend: $\operatorname{lm}$ - lamellar tissue; ilm - interlamellar tissue; plm - paralamellar tissue; al - albid tissue

Рис. 3. Распределение твердых тканей в Ра-элементах Siphonodella quadruplicata: 1 - SEM-изображение косого полированного сечения; 2 - томографическое сечение, отвечающее сечению на Fig. 3.1; 3 - положение сечения. Условные обозначения: lm - ламеллярная ткань; ilm - интерламеллярная ткань; plm - параламеллярная ткань; al - альбидная ткань

\section{References}

1. Donoghue P. C. J. Growth and patterning in the conodont skeleton. Philosophical Transactions of the Royal Society of London, B. № 353, 1998, pp. 633-666.

2. Frank-Kamenetskaya O. V., Rosseeva E. V., Zhuravlev A. V., Rozhdestvenskaya I. V., Banova I. I., Simon P., Buder J., Carrillo-Cabrera W., Kniep R. Hard tissues of S-elements of late Paleozoic conodont: microstructural and crystallographic aspects. Fedorov Session 2008. Abstracts. RMS DPI 2008-2-721, 2008, pp. 229-231.
3. Görög Á., Szinger B., Tóth E., and Viszkok J. Methodology of the micro-computer tomography on foraminifera. Palaeontologia Electronica Vol. 15, Issue 1; 2012, 15 p.; palaeoelectronica.org/content/issue-1-2012-technical-articles/121methodology-of-ct-on-forams

4. Goudemanda N., Orchard M. J., Urdy S., Bucher H., and Tafforeau P. Synchrotron-aided reconstruction of the conodont feeding apparatus and implications for the mouth of the first vertebrates. PNAS Early Edition, 2011, yflj e vfhbyrb d ,e[u cghjcbnm 

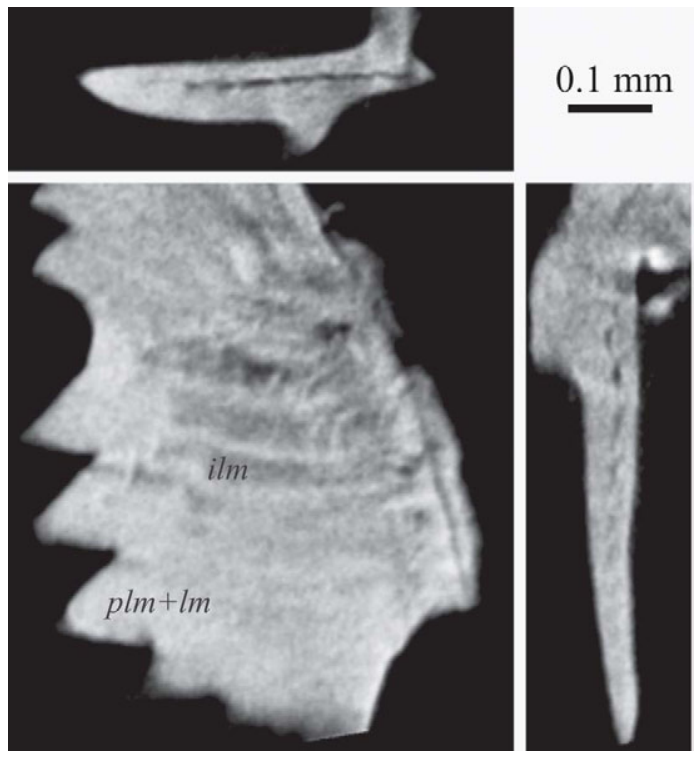

Fig. 4. Distribution of the interlamellar tissue in the free blade of Pa-element of Siphonodella quadruplicata. Interlamellar tissue is dark grey, lamellar and paralamellar tissues are light grey. Orthogonal slices of the tomogram ( $2 \mu \mathrm{m}$ voxel $)$

Рис. 4. Распределение интерламеллярной ткани в свободном листе Ра-элемента Siphonodella quadruplicata. Интерламеллярная ткань темно-серая, ламеллярная и параламеллярная ткани светло-серые. Ортогональные сечения томограммы (воксель $2 \mu)$

5. Murdock D. J. E., Dong X.-P., Repetski J. E., Marone F., Stampanoni M., and Donoghue P.C.J. The origin of conodonts and of vertebrate mineralized skeletons. Nature 502, 2013, pp. 546-549.

6. Pakhnevich, A.V. Study of fossil and recent brachiopods, using a Skyscan 1172 X-ray microtomograph. Paleontological Journal 44 (9), 2010, pp. 1217-2010.

7. Rosseeva E., Borrmann H., Cardoso-Gil R., CarrilloCabrera W., Frank-Kamenetskaya O. V., Oztan Y., Prots Y., Schwarz U., Simon P., Zhuravlev A. V., and Kniep R. Evolution and Complexity of Dental (Apatite-Based) Biominerals: Mimicking the Very Beginning in the Laboratory. Max-PlanckInstitutfbr Chemische Physikfester Stoffe, Scientific Report 20092010. 2011, pp. 171-176.

8. Shtyrlyaeva A. A., Zhuravlev A. V. The method of improving of resolution of X-ray microtomography. Vestnik $I G$. No. 6. 2016, pp. 24-27. (In Russian, with English abstract). DOI: 10.19110/2221-1381-2016-6-24-27

9. Tafforeau P., Boistel R., Boller E., Bravin A., Brunet M.,

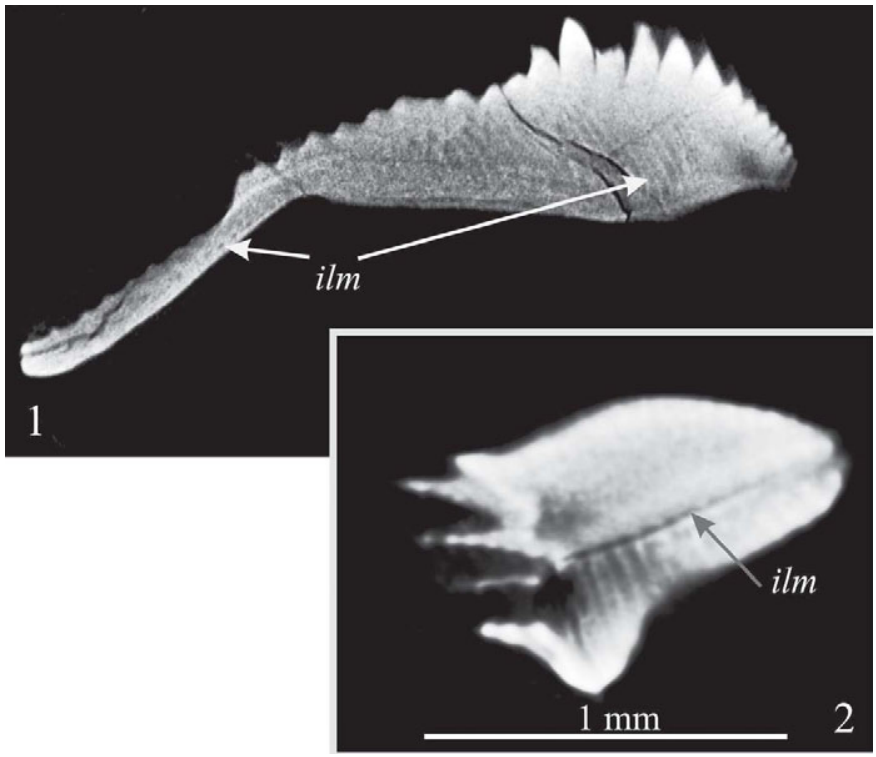

Fig. 5. Distribution of the interlamellar tissue (ilm) in the posterior process and free blade of the Pa-element of Siphonodella quadruplicata. Slices of the tomogram

Рис. 5. Распределение интерламеллярной ткани (ilm) в заднем отростке и свободном листе Ра-элемента Siphonodella quadruplicata. Сечения томограмм

Chaimanee Y., Cloetens P., Feist M., Hoszowska J., Jaeger J.-J., Kay R. F., Lazzari V., Marivaux L., Nel A., Nemoz C., Thibault X., Vignaud P., Zabler S. Applications of X-ray synchrotron microtomography for non-destructive 3D studies of paleontological specimens. Applied Physics A. 83, 2006, pp. 195-202.

10. Turner S., Burrow C. J., Schultze H.-P., Blieck A., Reif W.-E., Rexroad C. B., Bultynck P., and Nowlan G. S. False teeth: conodont-vertebrate phylogenetic relationships revisited. Geodiversitas 32 (4), 2010, pp. 545-594.

11. Zhuravlev A. V. Potentialities of computed microtomography for conodont elements study. Lithosfera, 2, 2013, pp. 163-166. (In Russian with English abstract).

12. Zhuravlev A. V. Morphology, histology, and ontogenetic changes of Pa elements of Siphonodella quadruplicata (Branson et Mehl) (conodonts, Early Carboniferous). Lithosfera, 4, 2014, pp. 100-105. (In Russian with English abstract).

13. Zhuravlev A. V., Vevel Y. A. Possibilities of computed microtomography application in micropalaeontological and lithological studies. Neftegazovaya Geologiya. Teoriya i Praktika. 7(2), 2012. available at: http://www.ngtp.ru/rub/2/ 21_2012.eng.pdf 